\title{
VIEWS OF STUDENTS WITH DISABILITIES ABOUT THEIR EXPERIENCE IN SECONDARY EDUCATION IN THE BASQUE COUNTRY, SPAIN
}

LÓPEZ, Ana Luisa. University of Deusto. (analuisa.lopez@deusto.es)

ETXABE, Eguzkiñe. FEVAS, Federación Vasca de Asociaciones de personas con Discapacidad intelectual y del Desarrollo. (educacion@fevas.org) MONTERO, Delfín. University of Deusto. (dmontero@deusto.es)

\begin{abstract}
Although most of students with intellectual and developmental disabilities have access and some even have completed secondary education in Spain, there are few studies that deepen on the students' views about their educational experience. The research team consisted of university researchers and professionals from a nongovernmental organization of people with disabilities. Three questionnaires were carried out, each one addressing a sample of key agents: students, their families, and educators. Qualitative and quantitative analysis presented focus on answers given by students. They positively value school climate, and admit having friends and receiving help from classmates and teachers. Some have suffered bullying, but they know who to ask for help. Opinions about their educational experience in class are tackled. They talk about methodological approaches used by teachers to make learning accessible and meaningful. It should be highlighted that they underline approaches that let them develop their autonomy and skills for adult life.
\end{abstract}

Keywords: students' views, secondary education, intellectual and developmental disabilities, special educational needs, inclusive education.

\section{Introduction to the research study}

Although most of students with intellectual and developmental disabilities (IDD) have access and some even have completed secondary education in Spain, there are few studies that deepen on the educational response given. Particularly relevant is the fact that few research has been done on disabled students' views about their experience in secondary education (Echeita \& Jiménez, 2007; FEAPS, 2009; Sierra \& Parrilla, 2014; Unión Europea, 2014). Both aspects have been fundamental while undergoing 
this piece of research.

The study "Assessing secondary education: educational response to students with intellectual and developmental disabilities in secondary education” aims to analyse the key elements that enhance quality of educational response given to those students with IDD in secondary education. Besides, it has the purpose to provide educational systems with recommendations and innovative proposals for improvement.

The research team consisted of researchers from the University of Deusto and professionals from FEVAS, the Basque Federation of Associations of People with IDD. The Department of Education of the Basque government financed the study. In addition, two of its institutions took part, the Basque Institute of Educational Assessment and Research (ISEI-IVEI) provided the team with the necessary information to build up the sample, and the Centres for Pedagogical Counselling and Innovation (Berritzegunes) gave access to each educational centre, their educators, students and families.

Three questionnaires were carried out which consisted of Likert scale closed questions and open-ended questions. Each questionnaire addressed a total sample of 206 individuals, divided into three key agents: 70 students, 63 parents or tutors of the participant students, and 73 of their educators.

The questionnaires for students and families were elaborated taking into consideration the results of the debates among people with DID and their families organized by FEVAS (Montero, Etxabe, Ricci, López \& Rojo, 2008). Each survey tackled the following areas: school climate; student's reference professionals; teaching and learning methodologies; collaboration among educators and professionals; personal program planning; communication and collaboration with families; coordination with external agencies; and resources for educators.

In this case, the qualitative and quantitative analysis presented focus on the answers given by disabled students about the school climate and the teaching and learning methodologies they experienced.

\section{School climate and teaching and learning methodologies, theoretical considerations}

School climate appears to be one of the key elements for promoting positive relationships among members of educational communities, particularly, students, 
educators and professionals, and families. Institutional conditions must be guaranteed so that school policies, cultures and practices foster presence, learning and participation of each school member, no matter their background, culture, social and personal conditions (Ainscow, Booth and Dyson, 2006; Echeita, 2006, 2013; López, 2008). Creating a positive atmosphere helps students to learn and develop social skills, significantly relevant for every child, disabled or not (Pujolàs, 2008).

Educational centres should give steps in order to become learning communities where everyone feel they belong, contribute, as well as learn from the experience they have as part of it. For this to happen, joint work and collaboration with families is needed. Giné (2014) points out that families' involvement promotes long-term changes in their children's behaviour.

"The fantasy of homogeneity" highly extended along secondary education should be replaced by the "logic of heterogeneity". Students with very different backgrounds and personal characteristics can work efficiently in heterogeneous environments. Thus, teachers and school leaders must develop and support contexts where diversity is contemplated as a fundamental resource for learners to enjoy rich educational experiences (Pujolàs, 2008).

Given the complexity of educational contexts nowadays, teaching and learning methodologies should focus on personalising learning, promoting individual autonomy, and establishing cooperative learning approaches (Coll, 2013; Pujolàs, 2004, 2008).

Personalising learning means that teaching is adjusted to the learner's characteristics. Coll (2013) underlines that student's learning trajectories must be considered when teaching. Those trajectories are defined as the group of contexts people have access to and where they participate. These trajectories are crucial because they provide the individual with opportunities and resources to learn.

Educational communities appear to be the only institutions that can help students to reflect and deepen on their learning experiences in each context of their trajectories, and build up their own learning identity (Coll, 2013). By analysing these trajectories schools can foster the necessary conditions that guarantee the acquisition of major basic learning and desirable basic learning. This is a key aspect in order that students develop learning autonomy, which is mainly relevant for those students with 
disabilities or special educational needs, because they can develop their own “regulating strategies for learning" (Pujolàs, 2008). Thus, they become aware about their learning experiences and reflect on them. They understand the way they learn and its purpose. In addition, they are able to recognise when they need help, how they need it, and who to ask for it (Coll, 2013).

A cooperative learning approach should be contemplated as the way of structuring day-to-day class activity, so that it becomes the heart of the teaching and learning processes within the class. Teacher, in this approach, is not the only person who teaches and support interactions among students promote peer learning (Pujolàs, 2004, 2008). In order to achieve it, natural support networks among classmates must be developed, so that it enhances material, moral and educational support (Stainback and Stainback, 1999). Facilitating, maintaining and optimising peer interaction among students with and without special educational needs remains crucial (Pujolàs, 2008).

\section{Opinions of students with DID about school climate and teaching-learning processes}

In Table 1., aspects valued by students can be observed, from higher to lower percentages.

Table 1. Students. School Climate.

\begin{tabular}{|c|c|c|c|c|c|}
\hline \multirow[t]{2}{*}{ SCHOOL CLIMATE } & \multicolumn{3}{|c|}{ OPINION } & \multirow[t]{2}{*}{ TOTAL } & \multirow{2}{*}{$\begin{array}{c}\text { Number of } \\
\text { cases }\end{array}$} \\
\hline & Highly agree & Not agree & NK/NA & & \\
\hline 11.1. I like my centre. & $98,53 \%$ & $1,47 \%$ & - & $100 \%$ & 68 \\
\hline $\begin{array}{l}\text { 15.1. In class, I feel well with my } \\
\text { classmates. }\end{array}$ & $92,65 \%$ & $7,35 \%$ & - & $100 \%$ & 68 \\
\hline $\begin{array}{l}22.1 \text { In the playground, I am with a } \\
\text { group of classmates. }\end{array}$ & $92,65 \%$ & $7,35 \%$ & - & $100 \%$ & 68 \\
\hline 12. I want to get out of this centre. & $5,88 \%$ & $91,18 \%$ & $2,94 \%$ & $100 \%$ & 68 \\
\hline 20.1 My classmates respect me. & $89,71 \%$ & $7,35 \%$ & $2,94 \%$ & $100 \%$ & 68 \\
\hline 10.1 In Secondary Ed. I'm happy. & $88,24 \%$ & $2,94 \%$ & $8,82 \%$ & $100 \%$ & 68 \\
\hline 21.1 My classmates help me. & $82,35 \%$ & $16,18 \%$ & $1,47 \%$ & $100 \%$ & 68 \\
\hline P9. In Primary Ed. I was happy. & $79,41 \%$ & $13,24 \%$ & $7,35 \%$ & $100 \%$ & 68 \\
\hline
\end{tabular}

Most of the students with DID like their school, above 98\%. It's also very high the number of learners who express feeling well with their classmates and being in the playground with them, more than $92 \%$. Almost $90 \%$ of them consider they are respected, and more than $82 \%$ think their classmates help them.

Students firstly value the social relationships they have in school, with educators, and above all, with classmates and friends. They express the support and help they receive 
from others is very important. They also talk about spending time with friends during breaks and worry about having problems with them.

In primary education I was happy with my teachers, classmates, games, studies and excursions. In secondary education, it was hard at the beginning, you need to adapt. Now I'm very happy with the teachers, and also with the classmates. Despite, I did not get along well with some people in the ordinary class. (Student, cod. 2076)

Secondly, the students name places and classes where they feel well, among them, the Task Learning Class (SAT, focused on skills for adult life), some subjects in common classes or segregated classes, and the playground. They thirdly value the work they do. They underline they like going to school to work, and they value the activities, particularly if they prepare them for adult life.

I'm learning a lot, to use materials (gardening, carpentry). We are reviewing subjects from earlier years. Sewing, the canteen, I like all. (Student, cod. 2076)

They treat me well, they don't reject me. (Student, cod. 1065)

Table 2. Students. School Climate, problems faced by students with DID

\begin{tabular}{|c|c|c|c|c|c|}
\hline \multirow[t]{2}{*}{ SCHOOL CLIMATE } & \multicolumn{3}{|c|}{ OPINION } & \multirow[t]{2}{*}{ TOTAL } & \multirow{2}{*}{$\begin{array}{l}\text { Number of } \\
\text { cases }\end{array}$} \\
\hline & Highly agree & Not agree & NK/NA & & \\
\hline $\begin{array}{l}\text { 16.1. I have problems with one or } \\
\text { some classmates, in class. }\end{array}$ & $17,65 \%$ & $82,35 \%$ & - & $100 \%$ & 68 \\
\hline $\begin{array}{l}\text { 16.1. I have problems... in the } \\
\text { playground. }\end{array}$ & $16,18 \%$ & $83,82 \%$ & - & $100 \%$ & 68 \\
\hline $\begin{array}{l}\text { 17.1. They laugh at me: in the } \\
\text { playground. }\end{array}$ & $16,18 \%$ & $82,35 \%$ & $1,47 \%$ & $100 \%$ & 68 \\
\hline 17.1. They laugh at me: in class. & $14,71 \%$ & $85,29 \%$ & - & $100 \%$ & 68 \\
\hline 18.1. They insult me: in class. & $13,24 \%$ & $85,29 \%$ & $1,47 \%$ & $100 \%$ & 68 \\
\hline $\begin{array}{l}\text { 18.1 They insult me: in the } \\
\text { playground. }\end{array}$ & $11,76 \%$ & $88,24 \%$ & - & $100 \%$ & 68 \\
\hline $\begin{array}{l}\text { 16.1. I have problems... at the } \\
\text { corridors. }\end{array}$ & $11,76 \%$ & $88,24 \%$ & - & $100 \%$ & 68 \\
\hline 19.1. They hit me: in class. & $11,76 \%$ & $86,76 \%$ & $1,47 \%$ & $100 \%$ & 68 \\
\hline $\begin{array}{l}\text { 19.1. They hit me: in the } \\
\text { playground. }\end{array}$ & $10,29 \%$ & $86,76 \%$ & $2,94 \%$ & $100 \%$ & 68 \\
\hline
\end{tabular}


Considering the problems that they may have experienced with other students or even bullying, as it can be seen in Table 2., youngsters manifest having problems with their classmates, particularly in class, more than $17 \%$. Some express they laugh at them, around 16\%; and they are insulted or hit, between 13 and $10 \%$. Comparing with the IVEI-ISEI Basque statistical data about bullying in secondary education in general, the percentage is $14.6 \%$ (Arregi \& Martínez, 2012), lower than in our study with students with DID.

Students who have suffer bullying talk about those situations, mainly fights, mocks and insults. They also comment on those who bully them. Most of them express they know who to ask for help, and that teachers are informed, although most of these problems happen when adults are not present.

They make fun of me because I use books from primary education. They laugh at me and hit me. (Student, cod. 1038)

I have had some fights with some classmates at the canteen. (Student, cod.

A girl insulted me, I told the TE (therapeutic educator). (Student, cod. 200)

Following, in Table 3., students' opinions about the teaching-learning processes experienced are divided into the classes they attend to: ordinary class, support class (several hours a week), segregated class (most of the time), and SAT (Task Learning Class).

Table 3. Students. Positive opinions about teaching and learning methodologies, considering type of class attended.

\begin{tabular}{|c|c|c|c|c|}
\hline \multirow[t]{2}{*}{ TEACHING AND LEARNING PROCESSES } & \multicolumn{4}{|c|}{ HIGHLY AGREE } \\
\hline & $\begin{array}{c}\text { Ordinary } \\
\text { class }\end{array}$ & $\begin{array}{c}\text { Support } \\
\text { class }\end{array}$ & $\begin{array}{l}\text { Segregated } \\
\text { class }\end{array}$ & SAT \\
\hline 23. In class, I understand the subjects and exercises. & $80 \%$ & $83.9 \%$ & $85.7 \%$ & $94.4 \%$ \\
\hline 24.2. In class, the teacher explains using examples. & $85 \%$ & $84 \%$ & $71.4 \%$ & $83 \%$ \\
\hline $\begin{array}{l}\text { 24.1. In class, the teacher puts pictures and } \\
\text { photographs in my material. }\end{array}$ & $60 \%$ & $67.7 \%$ & $71.4 \%$ & $61.1 \%$ \\
\hline 24.7. I do teamwork with my classmates. & $75 \%$ & & $57.1 \%$ & $83.3 \%$ \\
\hline 24.6. I work with a classmate who helps me. & $70 \%$ & $51.6 \%$ & $42.9 \%$ & $88.9 \%$ \\
\hline $\begin{array}{l}\text { 24.5. In class, my activities, exercises, and problems } \\
\text { are different from my classmates'. }\end{array}$ & $77.5 \%$ & & & \\
\hline $\begin{array}{l}\text { 24.4. In class, my books are different from my } \\
\text { classmates'. }\end{array}$ & $62.5 \%$ & & & \\
\hline $\begin{array}{l}\text { NUMBER OF CASES } \\
\text { The TOTAL is higher than the } 68 \text {, because some students attend } \\
\text { to more than one class, and answered about all the classes they } \\
\text { assist. }\end{array}$ & 40 & 31 & 14 & 18 \\
\hline
\end{tabular}


As it can be seen, most of the students understand the subjects and exercises, between $80 \%$ and $95 \%$. It seems that a majority of the teachers put examples when they give explanations, around $84 \%$ for all types of classes but one. Cooperative learning and peer-support seem to be used particularly in the SAT, higher than $85 \%$ manifest it, and in the ordinary class, around 70 and $75 \%$. In addition, a number of students express their teachers adapt the materials they work with, between 60 and $72 \%$. It must be highlighted that comparisons should be considered with caution given the fact that the number of students that answered about the ordinary and support class are much higher than in the other locations.

Considering the opinions about the ordinary class, it appears that there is still a common tendency to provide students with DID with different materials than the rest of the class, $77.5 \%$ of pupils manifested doing different activities and exercises, and $62.5 \%$ having different books.

Youngsters have a positive opinion about the way their teachers teach them. They give details about how they like to learn. Besides, they consider their classmates support them when they face difficulties. However, when analysing the answers given by their educators, it seems that, the peer support is not planned, but mainly happens naturally among them.

I like the way teachers teach. But I don't like some classmates. (Student, cod. 2038)

What I like is that the subjects are seen step by step, and when we finish we have free time to play and relax. (Student, cod. 1068)

In summary, they talk about the methodological approaches used by teachers to make learning accessible and meaningful. They underline those teaching and learning approaches that let them develop their autonomy and skills for adult life as fundamental purposes of their individual educational program. Besides, they express their interest in taking an active role in decision making about their learning process and personal development.

\section{Final words}

Given the participant sample, it should be underlined that the results must be analysed and generalized with caution. However, due to the characteristics of the population, 
students with IDD who have undergone secondary education, representativeness of the sample was highly considered. Thus, despite being a small sample, the data gathered provides with an overview of the situation of secondary education in the Basque country, particularly on those aspects that should be fostered in order to improve quality participation and learning among students with special educational needs. Besides, as inclusive research is underlying the relevance of children's and youngsters' voices, challenges on getting a representative sample and involving students in the research process must be foreseen. This is something to take into consideration for further research.

In relation to the analysis of the students' opinions, it seems that they are aware of their educational process, the way they learn and their motivations to conclude secondary education. However, it appears that some conditions should be guaranteed. On the one hand, a school climate that help students feel save and involved as part of the educational community should be necessary. Although positive opinions have been expressed a high percentage of students with DID express having suffered different types of bullying within the educational centre. Those situations jeopardize students' presence, participation and learning, limiting, at the same time, their emotional and social development.

On the other hand, cooperative approaches to learning and planned peer support may promote better ways of personalising learning experiences. As it can be perceived, these approaches are becoming a tendency within classes; but it appears to happen naturally, not planned. If teachers and other professionals take into consideration heterogeneity of class groups, and students' personal trajectories, they could get access to a bigger number of elements that each class has, and particularly important, include students' personal experiences, skills and characteristics as rich and useful teaching and learning resources. Thus, personal learning autonomy of teenagers and youngsters with DID would be enhanced, as well as, their capacities for adulthood. 


\section{Bibliography}

Ainscow, M., Booth, B. \& Dyson, A. (2006). Improving Schools, Developing Inclusion. Oxon: Routledge.

Arregi, A., \& Martínez, P. (2012). El maltrato entre iguales en educación primaria y ESO. Investigación 2012. Bilbao: ISEI-IVEI, Gobierno vasco.

Coll, C. (2013). La educación formal en la nueva ecología del aprendizaje: tendencias, retos y agenda de investigación. In J.L. Rodríguez Illera. Aprendizaje y educación en la sociedad digital (pp. 156-170). Barcelona: Universidad de Barcelona.

Echeita, G. (2006). Educación para la inclusión o educación sin exclusiones. Madrid: Narcea.

Echeita, G. (2013). Inclusión y Exclusión Educativa. De Nuevo "Voz y Quebranto". REICE, Revista Electrónica Iberoamericana sobre Calidad, Eficacia y Cambio en Educación, 11(2): 100-118. Retrieved from: http://www.rinace.net/reice/numeros/arts/vol11num2/art5.pdf

Echeita, G., \& Jiménez, D. (2007). Un estudio de casos sobre la situación académica, emocional y relacional de alumnos con necesidades educativas especiales asociadas a discapacidad intelectual integrados en IES. Siglo Cero. Revista Española Sobre Discapacidad Intelectual, 38(2), 17-43.

FEAPS. (2009). La educación que queremos Situación actual de la inclusión educativa en España. Madrid: FEAPS, Confederación Española de Organizaciones en favor de las Personas con Discapacidad Intelectual.

FEVAS \& Universidad de Deusto. (2013). La Secundaria a examen: la Respuesta Educativa del alumnado con discapacidad intelectual y del desarrollo (DID) en la educación secundaria. (Informe Científico, Noviembre 2013). Bilbao: FEVAS, Federación Vasca de Asociaciones de personas con Discapacidad intelectual y del Desarrollo. y Universidad de Deusto.

Giné, C. (2014). Conferencia "Plan de acción del orientador". Barcelona Inclusiva 2014, $1^{\text {er }}$ Congreso Internacional de Orientación para la Inclusión “Orientación para una Sociedad Inclusiva”, Barcelona.

López, A. L. (2008). Fomentando la Reflexión sobre la Atención a la Diversidad. Estudios de Caso en Chile. REICE, Revista Electrónica Iberoamericana sobre Calidad, Eficacia y Cambio en Educación,(6), 1, 172 - 190. Retrieved from http://www.rinace.net/vol6num2.htm

Montero, D., Etxabe, E., Ricci, A.C, López, A.L. y Rojo, I. (2008). El alumnado con discapacidad intelectual en la Educación Secundaria de la Comunidad Autónoma Vasca: situación y mejoras necesarias. Siglo Cero, Revista 
Española sobre Discapacidad Intelectual. Vol. 39 (4) Núm. 228, 51 - 61.

Pujolás, P. (2004). Aprender juntos alumnos diferentes. Los equipos de aprendizaje cooperativo en el aula. Barcelona: Octaedro, S. L.

Pujolàs, P. (2008). 9 ideas clave. El aprendizaje cooperativo. Barcelona, Graó.

Sierra, S., \& Parrilla, Á. (2014). ¿Una oportunidad igual para todos ? Investigando la transición a la educación secundaria en una comunidad socio-educativa. Revista Latinoamericana de Educación Inclusiva, 8(2), 85-102.

Stainback S. y Stainback, W. (1999). Aulas Inclusivas. Madrid: Narcea.

Unión Europea. (2014). Respondiendo a la diversidad contando con las voces de los estudiantes, una estrategia para el desarrollo docente. Experiencias de centros. Unión Europea. 